\title{
STRATEGIC GOALS OF THE EUROPEAN UNION IN MANAGING HEALTH SAFETY
}

\author{
doi: $\quad 10.2478 /$ czoto-2019-0023 \\ Date of submission of the article to the Editor: 30/11/2018 \\ Date of acceptance of the article by the Editor: 13/01/2019
}

Magdalena Bsoul-Kopowska ${ }^{1}$ - orcid id: 0000-0002-6167-6827

${ }^{1}$ Czestochowa University of Technology, Poland, magdalena.bsoul-kopowska@wz.pcz.pl

Abstract: With contemporary challenges and threats, health safety is more and more often taken into account in various European safety and health programmes. The European Union plays an important role in the improvement of public health, prevention and treatment of diseases, reduction in the number of sources of hazards to human health, and alignment of health strategies between member states. This paper presents the problems related to the management of health safety in the European Union. Furthermore, based on the analysis of EU documents, the strategic objectives of health safety management in member states were enumerated, with examples of coordination, cooperation and exchange of practices.

Keywords: European Union, management, health safety, strategic goals

\section{INTRODUCTION}

The fundamental role of every civilized country is to protect life viewed as a manifestation of biological human existence by creating and providing people with good conditions for health and health safety. Human life and health are values that are strongly interrelated and require special protection due to their value which is independent of other legally protected goods. Considering health as a good of special importance seems to be derived from the recognition of human life as a superior value (Rabiega, 2009). Therefore, the right to health belongs to the basic catalogue of rights, whose observance should be substantially supported by effective state policies to the extent guaranteeing health safety (Ruszkowski, 2010).

The World Health Organization defines health as a state of complete physical, mental and social well-being, enabling people to live a productive, sensible and creative lives in the social and economic areas, and the ability to play social roles, adapt to environmental changes, and cope with these changes (Dziadczyk, 2006).

Furthermore, health safety can be described as a "process that allows every person to increase their influence on health in terms of improving and maintaining good health status. Activities of both individuals and the entire communities are needed in order to ensure physical, mental and social well-being. These entities have to be able to specify and achieve their goals and satisfy basic needs while coping with the challenges and changes occurring in the surrounding reality. Therefore, health safety should be considered from standpoint of knowledge and resources that humans can 
utilize in everyday life. Since health means complete physical fitness of an individual and successful participation in social life, the responsibility for health safety lies not only with these people or merely with health care institutions. Actually, it depends on all areas of social activity that have a direct or indirect effect on human health safety" (Taranowicz, 2010).

Therefore, the basis for health policies that impact on health safety is to implement health promotion strategies. The tasks of health promotion include educating, showing the place of a human in the state structures, teaching how to maintain the ability to live at an essential level so that a person is able to cope with the challenges, and teaching how to minimize the risk of diseases (Sytnik-Czetwertyński and Cianciara, 2016).

Ensuring good health status has become the most important challenge for European citizens. Therefore, in accordance with the Article 168 of the Treaty on the Functioning of the European Union (TFEU), the achievement of a higher level of health protection is one of the most important objectives of the European Union within all European policies and activities. In particular, EU health policy aims to improve public health, prevent diseases and health hazards (including those related to lifestyles of EU citizens), and to combat serious health epidemics by promoting research.

Therefore, the European Union plays an important role in improving public health, preventing and treatment of diseases, reducing the number of sources of hazards to human health, and alignment of health strategies between member states. The European Union has successfully implemented a comprehensive policy in this area using the Health for Growth programme for 2014-2020 and the secondary legislation. The current institutional structure supporting the implementation of this policy is formed by the European Commission's Directorate-General for Health and Food Safety (DG SANTE) and specialized agencies, mainly the European Centre for Disease Prevention and Control (ECDC) and the European Medicines Agency (EMA) (http://www.europarl.europa.eu/ftu/pdf/pl/FTU_2.2.4.pdf )

The prerequisite for addressing this issue is the growing importance of health safety management to EU policies. Citizens' health has become one of the key priorities of the Community. EU health policies are implemented in connection with policies on the national levels of individual member states, with their objective being to guarantee access to high-quality health care for all EU citizens. Community initiatives are complementary to national policies, whereas the European Union encourages cooperation between member states in the area of health promotion. European health policy involves the development of joint competencies with the member states and the supplementation of national policies (European Commission, Legislative package, http://europa.eu/legislation_summaries/public_health/index_en.htm).

The aim of this paper was to present EU activities concerning health safety. Management of health care systems and providing health services is a responsibility of individual countries, but the EU can facilitate the achievement of shared common goals. Therefore, health safety management in the EU helps achieve the economies of scale that result from combining resources and solve problems that concern all the countries. These include combating pandemics, risk factors associated with chronic diseases, or the effect of increasing life expectancy on health care systems. 


\section{EU POLICY FOR HEALTH SAFETY}

The terms health and safety represent important categories, often referred to in the contemporary political, social and scientific discourse. An important premise for addressing these issues in a joint manner was the increasing importance of the problems of health safety for EU citizens. In scientific explorations, the areas of health and health safety have been discussed in the research fields of medicine, health policy, administration and military sciences. With the development of science, with particular focus on interdisciplinary domains that allow for a multifaceted exploration of the contemporary world, the categories of health" and health safety have become the focus of the research within many other scientific disciplines.

In the present paper, a comparative analysis of normative acts that stipulate health safety and health policy implemented in the European Union was used as a research methodology. The laws, acts, ordinances and guidelines concerning the creation of regulations aimed at elimination of threats to health safety and improving standards for health policy standards were analysed within the framework of EU legislation. In the Polish legal system, the starting point for consideration of the rights to health protection should be the Article 68 of the Constitution of the Republic of Poland. In paragraph 1, this article gives every person the right to health protection (Trzciński, 2003). Poland's accession to the European Union made it necessary not only to implement, but also to respect the Community standards.

The EU's strategic objectives for management of health safety and activities performed in this area were also discussed.

EU health policy was derived from regulations on occupational safety and health, and its further development resulted from the migration of people and exchange of goods in the internal markets, which required the coordination of problems concerning public health issues. The first documents on health protection can be found in the treaty regulations which laid the foundations for the entire EU. In 1951, the Treaty of Paris was signed, establishing the European Coal and Steel Community (ECSC), with its objective being economic growth, increasing employment rates and raising the quality of living in the founding countries, and ensuring conditions for a rational division of products). Furthermore, the importance of health both to individual citizens and the achievement of the objectives of integration was also emphasized. Undoubtedly, improved health status of the population contributes to the increased work performance, which is the basic factor in improving the standards of living of society. The term health was used in the Article 69 of the Treaty establishing the European Coal and Steel Community (ECSC), which obliged the member states to remove employment restrictions connected with nationality in the coal and steel industries. The next treaty regulations that addressed health issues were the two Treaties of Rome of 25 May 1957. They contained provisions on sanitary control, exchange of goods and the freedom of movement for labour concerning both health professionals and citizens (patients) within the Community states.

In 1987, the Single European Act implemented provisions regarding the requirement of a high level of health protection, especially the improved occupational safety and health and protecting the environment. Substantial changes concerned maintaining, protection and improvement of the quality of the environment, influence on the 
protection of human health and ensuring prudent and rational utilization of natural resources ( Wrzesińska - Wal, 2016).

This shows that the issues of health safety management have been, among other problems of the EU member states, addressed since the beginnings of the Community, despite the fact that its initial objective was quite general and recommended the achievement of a high level of health protection by raising living standards and improving working conditions

(http://www.europarl.europa.eu/ftu/pdf/en/FTU_2.3.5.pdf). It was further developed in the Maastricht Treaty (1991), followed by the Treaty of Amsterdam (1999).

The European Social Charter (Article 11) of 1991 also stipulated the citizens' right to protect the health and indicated the necessity of elimination of the causes of diseases, introduction of facilitations in the area of counselling and education aimed to improve health and instil individual responsibility for the health, preventing epidemic diseases, endemic diseases etc.

The EU health policy is aimed to improve public health, prevent diseases and health threats (including those related to lifestyles of EU citizens), and combat serious health epidemics by promoting research. The most important EU's objectives for the development of health safety include:

- disease prevention;

- promotion of healthy lifestyles;

- care for good mental health;

- protecting the population from serious health hazards with an international impact;

- improved access to healthcare;

- popularization of information on health and supporting health education;

- providing safety for patients;

- supporting dynamic healthcare systems and new technologies;

- establishing high quality and safety standards with regards to organs and other substances of human origin;

- providing safe, effective and high-quality medical products (http://eurlex.europa.eu/legal-content/PL/TXT/?uri=CELEX\%3A12016E168 ).

\section{EU ACTIVITIES IN THE FIELD OF HEALTH SAFETY MANAGEMENT}

Before the current Treaty was adopted and despite the lack of transparent legal basis, the health safety policy implemented as part of the EU activities concerned:

- medicinal products: legislation adopted after 1965 aimed to ensure high standards for scientific research and drug production, alignment of national procedures for the authorization of medicines and the implementation of the principles concerning advertising, labelling and distribution. In 2011, the Parliament adopted the 'pharmaceutical package', which concerned, among other things, pharmacotherapy;

- research centres: medical research programmes and public health research programmes were implemented already in 1978 and addressed health problems related to age, environment and lifestyles, radiation hazards and analysis of the human genome, with particular focus on the most common diseases. These health issues and other emerging problems have been addressed in the 7th EU's Framework Program. This research is continued by the 2020 Horizon programme;

- mutual support: member states agreed to provide mutual support in the event of natural disasters or exceptionally serious diseases; over the last twenty years, many 
of these issues have raised public concerns: mad cow disease (BSE, or bovine spongiform encephalopathy), swine influenza, H1N1 flu, Zika virus and others;

- in 2013, the Parliament adopted a position on the legislation concerning crossborder provision of health services and the revision of the legal framework relating to medical equipment and advanced therapies (expecting the agreement with the Council).

In 1993, the Commission published a communication on the framework for action in the field of public health which stipulated eight areas of action, thereby laying the foundations for the first many-year public health programme and subsequent programmes. These programmes were implemented in 1996 - 2002. These eight programmes concerned:

- health promotion: healthy lifestyles; nutrition; alcohol, tobacco products and drugs, medicines;

- health monitoring: collaboration-based programme including a data collection centre;

- 'Europe in the fight against cancer': epidemiological analyses and surveys;

- drugs: the EU centre in Lisbon; the UN convention; bilateral contacts with countries where drugs are produced;

- AIDS and infectious diseases: information campaigns, education and preventive measures;

- injury prevention: accidents in leisure time; special emphasis on children, adolescents and older adults;

- diseases caused by the environmental pollution: more accurate data; risk perception; special emphasis on respiratory diseases and allergies;

- rare diseases: EU database;

- exchange of information; early detection $n$ (http://eur-lex.europa.eu/legalcontent/PL/TXT/?uri=CELEX\%3A12016E168).

In 2003-2008, the EU implemented the first programme in the field of public health. In order to ensure more efficient management and establish rules for the implementation of health policies, the Community announced the second Community action programme in the field of public health for 2008-2013. The objective of these strategies is to promote health among the ageing European population, protect citizens from health hazards and support dynamic health systems and new technologies.

In February 2013, the European Commission adopted a social investment package to promote economic growth and cohesion. In the respective section, health was defined as not a value in itself, but a prerequisite for well-being. The document stresses the need for investing in sustainable health care systems and human health (Ślusarz and Mitela-Grzybek, 2013). In contrast, in March 2014, the third European Union health programme was adopted for 2014-2020. The following priorities have been implemented within this programme: health promotion, disease prevention with consideration for the health-in-all-policies approach, protecting EU citizens against serious cross-border health hazards; improving innovativeness, efficiency and stability of healthcare systems and making it easier for EU citizens to get access to better and safer healthcare (https://ec.europa.eu/social/healthandsafety).

In recent years, EU safety initiatives have focused on the three most important aspects with a direct impact on health safety strategies:

1. Consolidation of the institutional framework - The role of the Parliament as a co-decision making body (deciding together with the Council) was reinforced with 
regard to issues related to the health, environment, food safety and consumer protection. The way in which the Commission undertakes legislative initiatives was improved using standard consultation procedures between the services, new regulations on the comitology procedure (this is because decisions are made in committees of the European Commission. They are composed of the representatives of the member states, with a chair held by the representative of the Commission) and through the dialogue with representatives and experts from civil society. In 2005, the Executive Agency for Health and Consumers (EAHC) was established to improve the implementation of the Community public health programme.

2. The need for improving early reaction capabilities; currently, an important challenge for the European Union is the ability to respond quickly and in a coordinated way to the major threats to public health safety, especially in the context of the threat of bioterrorism and global epidemics facing the fast global transport that accelerates the spread of diseases.

3. The need for better coordination of health promotion and disease prevention; the aim of these actions is to combat the main causes of health problems caused by unhealthy lifestyles of individuals and economic and environmental factors. The achievement of these goals consists in close collaboration in other areas of EU policies, such as the environment, transportation, agriculture and economic growth, as well as consultations with all involved parties. The key initiative is to develop a mechanisms of social consultations on health issues.

\section{CONCLUSION}

Health safety is more and more often included in European safety and health programmes. The European Commission and EU member states implement a comprehensive programme of work in the field of health safety, coordinated by the Health Safety Committee whose members include senior officials from the member states and the European Commission in order to examine issues related to health safety and strengthening collaboration at the EU level. The Commission acts as a liaison body between GHSI and the Health Safety Committee to ensure consistent work conducted by these institutions.

A noticeable tendency in activities concerning health safety management is also observed in the more common use of information technology and the popularization of the use of mobile devices (smartphones and tablets) and smart applications, which allows all entities in the sector to have universal, 24/7 access to services. There are ongoing discussions on emerging scenarios in the field of e-health and $\mathrm{m}$-health.

Poland's accession to the EU allowed for the implementation of all the abovementioned EU strategies in order to increase health safety and the use of EU subsidies, which contributed to the improvement of conditions in hospitals and outpatient clinics or the purchase of new medical equipment. With these subsidies, the modernization of emergency medical services was also refunded, including the purchase of new ambulances, construction, reconstruction or refurbishment of voivodeship emergency notification centres, which is expected to lead to a reduction in mortality in sudden life-threatening events.

The following projects were implemented using the EU funds:

- Development of comprehensive prevention programmes adjusted to the needs of individual employee and professional groups, with particular focus on the the reduction of occupational diseases. 
- Development of comprehensive programmes to help specific groups of employees and vocational groups suffering from occupational diseases and people after longterm incapacity to work caused by the diseases indirectly related to working conditions to return to professional careers.

- Professional training for nurses and midwives as part of bridging university courses. Professional training for physicians, paramedics and medical emergency dispatchers in the area of emergency medical services.

- Specialization of medical professionals with deficit specialities: oncologists, cardiologists and occupational physicians.

- Professional nursing in the medical rescue system in Poland - post-graduate education.

- Training for employees and hospital management staff on cost account and management information and tools for restructuring and consolidation of health care units.

- Support for the accreditation of health care units.

- Training for management staff in hospitals providing health services financed from the resources of the National Health Fund or from other public funds, and training for management staff in the National Health Fund,

- training in cost account and management information and tools for restructuring and consolidation of health care units for employees, especially for management staff and employees of founding bodies,

- development of qualification standards for management staff in the health care sector,

- development and implementation of a prevention programme for early detection of genitourinary cancers in working men aged over 45 years (Warchoł, 2017).

\section{References}

Smith M.W., DeBakey M. E., Resilient Practices in Maintaining Safety of Health Information Technologies. VA Medical Center, Houston, Texas, Ash J. S., Oregon Health and Science University, Portland, Sittig D.F.,University of Texas, Houston, and Hardeep Singh, DeBakey M.E., VA Medical Center, Houston, Texas. https://www.ncbi.nlm.nih.gov/pmc/articles/PMC4361460/, doi: 10.1177/1555343414534242 (accessed on 28 November 2018)

The National Centre for Health Information Systems, EU Funds 2007 - 2013. http://www.csioz.gov.pl/wiw/index.php/fundusze-unijne-2007-2013.html, (accessed on 28th November 2018)

Dziadczyk B, 2006. Health care models. M. Pierzchalska (ed.) Globalization processes and economic thought of the Catholic Church, Wyd WSB. Radom.

EU grants, Priority XII Health safety and improvement of the effectiveness of the health care system.

http://www.dotacja-unijna.com/unijne,link-24,podlink-

37.html,Program+Operacyjny+Infrastruktura+i+Srodowisko,Bezpieczenstwo+zdr owotne+i+poprawa+efektywnosci+systemu+ochrony+zdrowia ( accessed on 28th November 2018)

European Social Fund in the Ministry of Labour and Social Policy, Measure 2.3.1 Development of comprehensive health programmes. 
http://www.kapitalludzki.gov.pl/o-programie/priorytet-ii/dzialanie-23/poddzialanie231/, (accessed on 29th November 2018)

European Social Fund in the Ministry of Labour and Social Policy, Measure 2.3.2 Professional improvement of medical human resources. http://www.kapitalludzki.gov.pl/o-programie/priorytet-ii/dzialanie-23/poddzialanie232/. (accessed on 29th November 2018)

European Social Fund in the Ministry of Labour and Social Policy, Measure 2.3.3 Improving the quality of management in health care,

http://www.kapitalludzki.gov.pl/o-programie/priorytet-ii/dzialanie-23/poddzialanie233/. (accessed on 28th November 2018)

European Social Fund in the Ministry of Labour and Social Policy, Measure 2.3.4 Development of human resources qualifications to improve the quality of health care management. (accessed on: 27th November 2018).

Structural Funds, Operational Programme Human Capital 2007-2013, http://www.funduszestrukturalne.gov.pl/NSS/programy/krajowe/pokl/(accessed on: 30th November 2018).

Ikeogu D.O., Uwakwe J.O., Chidolue I.B., 2013. The Effect of Health Safety Management in National Development. Mediterranean Journal of Social Sciences Published by MCSER-CEMAS-Sapienza University of Rome, Vol 4 (7), http://www.mcser.org/journal/index.php/mjss/article/view/685.

DOI: $10.5901 / \mathrm{mjss} .2013 . v 4 n 7 p 93$, p.93 (accessed on 28th November 2018).

Ministry of Health, Department of European Funds, Man: the best investment. http://zdrowie.gov.pl/portal/downloadLink.html?file_id=2405\&pid=241 (accessed 28th November 2018)

Ministry of Health, European Funds in health care. http://www.mz.gov.pl/rozwoj-iinwestycje/fundusze-europejskie-dla-sektora-ochrony-zdrowia. (accessed on 28th November 2018)

Rabiega A., 2009. Protection of human life and health in the activities of administrators in the area of health care. Wydawnictwo Sejmowe, Warsaw.

Ruszkowski J., 2010. Increasing health safety, expertise commissioned by the Ministry of Regional Development. Warsaw.

Sytnik-Czetwertyński J., Cianciara D., 2016. The individual face to face with public health: a conflict of interests or a conflict of conditions? Journal of Education, Health and Sport, 6(2):223-237, eISSN 2391-8306.

DOI http://dx.doi.org/10.5281/zenodo.46590, (accessed on 28th November 2018).

Ślusarz B, Mitela-Grzybek A., 2013. Health safety of the inhabitants of the European Union with particular emphasis on the new financial perspective based on the example of Lubusz Voivodeship. Scientific and Methodological Review. Education for Safety, 4, 269-278, 271.

Taranowicz I., 2010. Health and methods to deal with health threats. Sociological analysis. Oficyna Wydawnicza Arboretum, Wrocław.

Warchoł M., 2017. EU subsidies in the years 2007-2013 and the health care system in Poland. Journal of Education, Journal of Education, Health and Sport, 7 (5), 401409.

Iwona Wrześniewska-Wal. Public health in EU regulations: Postępy Nauk Medycznych 5/2016, 322-326 
http://www.europarl.europa.eu/ftu/pdf/pl/FTU_2.2.4.pdf. (accessed on 28th November 2018).

http://www.europarl.europa.eu/ftu/pdf/en/FTU_2.3.5.pdf. (accessed on 28th November 2018).

http://eur-lex.europa.eu/legal-content/PL/TXT/?uri=CELEX\%3A12016E168.

(accessed on 28th November 2018)

https://ec.europa.eu/social/healthandsafety. (accessed on 28th November 2018) 